\title{
Features of landscape design of eco-spaces for the purpose of education and upbringing of eco-culture in modern society
}

\author{
Pavel Vasilenko ${ }^{1, *}$, Elena Vasilenko $^{1}$, Natalia Barsukova $^{2}$, Valentina Pallotta ${ }^{3}$, and Tatyana \\ Sichkar ${ }^{4}$ \\ ${ }^{1}$ Federal State Budgetary Educational Institution of Higher Education " Moscow State University of \\ Technology and Management named after K. G. Razumovsky (First Cossack University)" \\ ${ }^{2}$ National Design Institute, Russian Federation, Moscow \\ ${ }^{3}$ Moscow international University, Leningradsky prospect, 17, Moscow, Russian Federation \\ ${ }^{4}$ Institute of World Civilisations, Moscow, Russia
}

\begin{abstract}
The article discusses the issue of designing the landscape and architectural environment of eco-spaces for the purpose of eco-education and upbringing. Since the main solution to environmental problems is the education of ecological culture, the formation of a new type of ecological consciousness among the younger generation, the design of eco-sites is the most relevant solution in this area. After analyzing the existing eco-sites and eco-trails, we can draw certain conclusions and identify several factors that are necessary when designing landscape eco-spaces. The creation of an eco-platform on the territory of park zones will attract the attention of the population to the problems of environmental pollution, as well as the education of ecological culture and the popularization of ecological and educational activities among young people. Visitors to the site, aimed at eco-education, will plunge not just into the architectural and landscape area, but into a whole educational camp, where everyone can find a convenient way to get information. The modern, designed space will be able to promote the development of creative and research abilities of children during the summer and winter holidays. The complex should include such areas as: entrance, exhibition, administrative and office premises, recreation area, area of cultural events, master classes, lectures. For the perception of a holistic environment, it is necessary to preserve the unity of the composition and create a thematic planning structure of the eco-space. A prerequisite is that the development of the relationship between the premises and the multi-level space provides for the logical movement of visitors around the ecological site. People who are immersed in the process of observing nature will do this in a constant mode, studying the growth of plants, changes in the weather, and so on.
\end{abstract}

\footnotetext{
*Corresponding author: author@email.org
} 


\section{Introduction}

Environmental education and education is an extremely important problem of the present time. The main option for solving environmental problems is the education of ecological culture, the formation of a new type of ecological consciousness in the younger generation. This is contained in such normative legal acts as: the Decree of the President of the Russian Federation "On the concept of the transition of the Russian Federation to sustainable development" (1996), in the "Environmental Doctrine of the Russian Federation" (2002).),

National projects "Ecology" (2019-2024), "Education" (2019-2024), the Federal Project "Success of every child", "New opportunities for every child", etc. To date, according to the existing standards, environmental education must be performed both at regular and nonregular times within the educational program (The Law" On Education in the Russian Federation " of 2012).

It is worth noting that there are no specific standards for preschool education, only a few organizations implement original educational programs. Comparing the current picture with the previous situation, it turns out that environmental education has received less attention. At the school level, eco-education is carried out in such subjects as "The world around us" ("Natural Science") or other subjects with a natural scientific bias. Such lessons are aimed not only at eco-education, but also at the study of natural, social and environmental processes [1].

\section{Materials and methods}

For the implementation of the scientific research, the method of scientific analysis of existing ecological sites, their relevance and impact on the education of ecological culture among the modern young generation was applied. The materials used to implement the solution of the research problems are based on the study of different approaches in the landscape design of eco-sites with different requirements, in different natural and climatic conditions.

\section{Results}

In Russia, environmental centers with additional eco-education are being developed, aimed at deepening children's knowledge in the study of nature. It is carried out by training through the use of interactive technologies; visits to eco-camps, eco-sites, eco-trails; field classes with the involvement of parents to solve certain educational tasks in the field of ecology [2].

To date, several of the most pronounced aspects of environmental education can be identified: the inability to fully implement educational programs in the field of ecology against the background of conflicting interest in this topic among students and teachers; the reduction in the number of professionals in the field of environmental sciences; the emergence of a "fashion" for ecology, the call for eco-education in informal ways through the media, Internet resources [3].

The implementation of the tasks set for environmental education in the territories of eco-trails or eco-sites depends entirely on the landscape and architectural design of these places. The main condition for this design is ergonomic accessibility and convenience, interest, and competent formation of training elements. 


\section{Discussion}

In accordance with the approved requirements of the national project "Education", as well as with the use of standard models, by 2024 it is necessary to form a network of at least 150 centers of advanced additional professional education on the basis of the existing network of educational organizations implementing additional education programs.

Great attention should be paid to the issues of modernization, improvement and reconstruction of urban parks, focusing their landscape architecture on the requirements of modern times. Creating an architectural and landscape environment that is opposite to the city will have a positive effect on the well-being and mood of the city's residents [4]. The design and organization of an eco-site for ecological and educational purposes of the territory of the park zone, assumes the availability of appropriate material and technical base, resources and ensuring the functioning of the infrastructure [5]. But, despite the developed infrastructure and transport accessibility, the potential of the eco-center, it is necessary to pay attention to ways to improve the effectiveness of the implementation of the eco-educational potential of the eco-center through the design, organization and creation of new modern eco-sites, biodiversity conservation, as well as updated educational programs, methods, and training content [6]. The creation of an eco-site on the territory of the park will provide an opportunity to attract the attention of the population to the problems of environmental pollution, as well as to foster an ecological culture and popularize environmental and educational activities among young people. The modern, designed space of the ecological park promotes the development of creative and research abilities of children and adults [7].

An example of such a park is "Zatyumensky", organized on the outskirts of Tyumen. The territory of this park was a forest belt without any organization of space. In 2018, landscaping was completed with a total area of 77 hectares. The eco-park area is well lit, the paths are covered with wood chips. Special attention should be paid to the dozens of sculptures made of natural materials placed in the park. The park is equipped with bike paths, playgrounds for playing mini-football, basketball, volleyball, tennis.

"Lesnoy Klyuch" a in the Nizhny Novgorod region is surrounded by a forest and a lake. The park is characterized by a variety of types of trees and shrubs. Lake Klyuchik with clear turquoise water does not freeze even in severe frosts. The Holy Trinity Ostrovozersky Monastery of the XVI century and a recreation center are located on the territory.

The park "Lukomorye", founded in Sevastopol in 1984 as a children's town, was constantly reconstructed. Today it is a modern ecopark, which is popular with children of different ages and adults. This park is interesting - "Gold Mines", where you can find real precious stones. At the master class, what you find will turn into a piece of jewelry. Also, various mini-zoos, neskuchnye museums, an ice slide gives you the opportunity to learn a lot about the surrounding nature.

The architectural structures are made of ecological materials and are surrounded by numerous trees.

"Yasnoye Polye" Park near the village of Velezhevo, Tula region, on the lake shore, among hundreds of trees. This park is distinguished by the fact that it actively develops a variety of fields of activity: cheese making, farming, horse yard, ceramic workshop, other areas. By studying crafts, folk culture and art, visitors are introduced to nature.

"Kenozersky National Park" of the Arkhangelsk Region, a park where the culture of the Russian North is preserved. In the natural and cultural complex of Kenozerye there are natural objects and architectural monuments. While relaxing, visitors will learn about the local way of life and the local nature-by walking along ecological trails. Solar panels are installed on many objects of the park zone, and other types of renewable energy sources are also being developed. 
The ecological trail in Moskovsky in the city of Moscow appeared in the summer of 2019. A new ecological route that runs from the third microdistrict of Moskovsky to the village of Meshkovo and is called "Ecological Trail" The road passes through the forest, around a lot of different shrubs and trees. Along the route, there are small stands where you can read about what plants grow around, what animals and birds live in this forest.

\section{Conclusion}

Based on the above analysis, we can identify several factors that are necessary when designing landscape eco-spaces:

- the complex should include such areas as: entrance, exhibition, administrative and office premises, recreation area, area of cultural events, master classes, lectures;

- maintaining the unity of the composition is the main component for a holistic perception of the environment by visitors [8]. A person should have a complete imaginative impression of architectural structures and exhibits;

- the creation of the planning structure of the eco-space is a prerequisite for the design, which corresponds to the thematic nature of the displayed objects, exhibits, installations and structures [9];

- the development of the interconnection of premises provides for the logical movement of visitors around the ecological site;

- creating a multi-level space that will contribute to the efficiency of the flow of visitors.

Thus, the development of the design concept for the formation of the architectural and landscape environment of the eco-site includes a two-level system of functional zoning, the integration of small architectural forms, decorative paving and landscaping, which contributes to a comfortable stay for visitors of all ages [10].

Design-the concept of forming the architectural and landscape environment of the ecosite, includes a two-level system of functional zoning, integration of small architectural forms, decorative paving and landscaping, which contributes to a comfortable stay for visitors of all ages [11].

Visitors to the site, aimed at eco-education, will plunge not just into the architectural and landscape area, but into a whole educational camp, where everyone can find a convenient way to get information [12]. People who are immersed in the process of observing nature will do this in a constant mode, studying the growth of plants, changes in the weather, and so on.

On the territory of the eco-site, all conditions must be created for the implementation of the education program, for conducting various training events, so that the site is visited daily, and it is possible to keep your own observation records, immersing yourself in natural processes [13]. Passion and immersion not only in the research process, but also in the creative process, which will eventually teach you to take care of nature and solve problems in practical ways [14].

Thus, the main task of landscape design on the territory of park zones is to create a site of an ecological and educational center for organizing educational and propaganda work, attracting public attention to the problems of environmental pollution, educating environmental culture and popularizing it among young people [15].

\section{References}

1. V. I. Pallotta, Russia and the world: The Development of civilizations. Transformation of political landscapes in the period 1999-2019, 432 (2019) 
2. J. Gibson, Ecological approach to visual perception, 464 (1988)

3. M. C. Kondo, E. C. South, C. C. Branas, J. Urban Health, 92(5), 814 (2015)

4. S. Raffle, Environment and Planning B: Planning and Design, 4

5. R. Ulrich, R. Simons, B. Losito, E. Fiorito, M. Miles, M. Zelson, J. Environ. Psychol., 11, 230 (1991)

6. M. C. Power, The relation between past exposure to fine particulate air pollution and prevalent anxiety: observational cohort study (2015)

7. A. I. Fursov, P. Mudu, M. Braubach, M. Martuzzi, Urban green and health (2016)

8. P. G. Vasilenko, E. V. Vasilenko, E. S. Pruzhina, Modern trends in fine, decorative and applied arts and design, 1, 34 (2019)

9. E. V. Fomina, N. I. Barsukova, Interciencia. 44(4), 156 (2019)

10. F. A. Cerver, The World of Architecture, 1000 (2000)

11. A. Isozaki, The international design yearbook 1988/89, 2409 (1988)

12. M. Lancaster, Colourscape. Academy Editions, 128 (1996)

13. J.-Ph. Lenclos, D. Lenclos, Couleurs du monde, 240 (1999)

14. W. Auschner, Colour in town, 51 (1990)

15. E. V. Lopasova, Formation of the aesthetic image of the urban environment by means of modern monumental art, 354 (2014)

16. P. G. Vasilenko, E. V. Vasilenko, E. S. Pruzhina, Modern trends in fine, decorative and applied arts and design, 1, 34 (2019) 